\title{
DIVERSITY OF ACTINOMYCETES FROM EKA KARYA BOTANICAL GARDEN, BALI**
}

\author{
SHANTI RATNAKOMALA ${ }^{1 *}$, PUSPITA LISDIYANTI ${ }^{1}$, NITA R. PRAYITNO ${ }^{1}$, EVI TRIANA ${ }^{2}$, \\ Y ULIN LESTARI ${ }^{3}$, RATIH D. HASTUTI ${ }^{4}$, YANTYATI WIDYASTUTI ${ }^{1}$, MISA OTO GURO $^{5}$, \\ KATSUHIKO AND ${ }^{5}$ and ENDANG SUKARA ${ }^{1,4}$ \\ ${ }^{1}$ Reserch Center for Bidtechnogy, Indonesian Instituteof Saienes Cibinong16911, Indonesia \\ ${ }^{2}$ Reserch Center for Bidogy, Indonesian Institute of Saienes, Cibinang16911, Indonesia \\ ${ }^{3}$ Department of Bidogy, Faalty of Mathematics andNatural Saienes Institut Petanian Bogr, Bogor 16680, Indonesia \\ ${ }^{4}$ Sail Research Institite, Bocor 16002, Indonesia \\ ${ }^{5}$ NITE Bidojial ResaurceCenter (NBRC), 2-5-8 Kasuzakamatan, Kisarazu, Chiba, Japan
}

Received 1 July 2015/ Accepted 6 May 2016

\begin{abstract}
ABST RACT
A total of 229 strains of actinomycetes were isolated and identified by full sequence of $16 \mathrm{~S}$ rRNA gene analysis. Samples consisted of 18 soil and 20 leaf-litter were collected from Eka K arya Botanical Garden, Bali Island, Indonesia. Two isolation methods, i.e. SD S-Y east Extract (SY) and Rehydration-Centrifugation (RC) were used in this study. Based on 16SrRNA gene analysis, isolated actinomycetes may be grouped into 28 genera. Based on molecular analysis of 16S rRNA gene similarities showed that isolated actinomycetes of Eka Karya Botanical Garden origin is diverse. Analysis on 144 isolates from soil samples, resulted in 24 genera and more than 87 species. Stretomyess is the most dominant genus where 65 isolates or $45 \%$ from isolated actinomycetes belong to this genus. It was followed by Adinqdanes $(25$ isolates $=17 \%$ ). From leaf-litter samples, the total number of 85 isolates may be grouped into 9 genera and more than 41 species. The most dominated genus is Adinqlanes $(42$ isolates $=49 \%)$ followed by Catenulquanes $(16$ isolates $=19 \%$ ).
\end{abstract}

Keywords: 16SrRNA gene analysis, actinomycetes, biodiversity, Eka Karya Botanical G arden

\section{INTRODUCTION}

Actinomycetes are microorganisms belong to gram positive bacteria which are often saprophytic while some of them produce spores and mycelium. They play important roles in degrading and decomposing organic compounds in the soil. They may also produce secondary metabolites such as antibiotics, enzymes and other bioactive compounds for human welfare. Actinomycetes constitute a significant component of the microbial population in most soils and counted of over 1 million cells per gram of soil. Soil is, therefore, the most prolific source of this particular group. Soil represents the most intensively studied habitat of actinomycetes.

\footnotetext{
* Corresponding author: shanti_ratna@yahoo.com

** This paper was presented at symposium on Recent Advances on Microbiological Researches and its Application (8-9 November2011). Serpong, Indonesia.
}

Actinomycetes are also thought to be the most significant group in the degradation of relatively complex, recalcitrant polymers found naturally in plant litter and soil (Hopwood 2007; Baskaran eal. 2011).

The preliminary characterization of the actinomycetes isolates was colony appearance, observing of zoospore bearing isolates, and DAP analysis. DAP analysis itself is a biochemical analysis of cell walls to observe the DAP isomers of the cell wall of actinomycetes. Most of gram positive bacteria have lysine instead of DAP in their cell wall. Through this method, actinomycetes could be grouped into 3 groups. According to Miyadoh (2004), actinomycetes that have LL-DAP in their cell wall generally belong to genus Streptamcesand Streptadidphilus while those with moDAP type in their cell wall generally belong to the non-Streptomyces or so called rare actinomycetes. Actinomycetes that have both 
LL-DAP and meso-DAP usually belong to genus Kitasatospara. Therefore, the DAP analysis could differentiate those three types of actinomycetes.

Some actinomycetes share the same ability to release flagellated zoospores at a certain stage in their life cycle (Cross 1986). Current classification of motile-spored actinomycetes can identify at least six suborders containing zoosporic genera, including Mioromonosporinae, Miorococinae, Frankinae, Psandonocardinae, Kineosponiineae and Streptosporanginee(Stackebrandt \&al. 1997). These zoospores bearing actinomycetes have been associated with river, lake and fresh water, river sediments, desert soil (G arrity \&al. 1996; Bredholt e al. 2008; Sibanda \& al. 2010), decaying plant materials submerged in streams and cast up on lake shores (Kudo đal. 1998; Tamura \&al. 2010), blades of grass inhabiting streams and soils (Hasegawa 1991). It has become increasingly apparent that motile actinomycetes can produce a variety of antibiotics and other bioactive metabolites or be used for biochemical conversion of complex compounds (Hasegawa 1991; Garrity \& al. 1996; Khamna \& al. 2010; Khanna đal. 2011).

According to Hayakawa \& al. (2000), actinomycetes could be divided into two types based on spores produced by the non-motile and motile. Actinomycetes which bear non-motile spores that are not generally form flagella, for example, are Streptamyes Nocardia, Mirommospara, and so on. Adtinqdanes and Catemulqulanes are motile zoospores bearing actinomycetes and the zoospores can move. Several actinomycetes genera such as Adinoplanes, Amyodatopsis, Catenuloplanes, Dadylosporangium Kineosporia, Micodispora, Micrommospora and Nonomiram are often very difficult to isolate and cultivate due to their slow growth and those belong to the rare actinomycetes (Hayakawa 2008).

Eka Karya Botanical Garden, in Bedugul, Bali Island, Indonesia is a unique $\mathrm{e}$ situ plant conservation site for plant species of high elevated eastern tropical rain forest of Indonesia, adjoining with the tropical forest of Batukahu nature reserve. This garden is located at 1,250$1,450 \mathrm{~m}$ above sea level, with area of 157.5 hectares (389 acres). Temperature is about 17$25{ }^{\circ} \mathrm{C}$ in daytime and is dropped to $10-15{ }^{\circ} \mathrm{C}$ at night with 70-90\% humidity (Mukaromah \& Suparta 2007). Based on the uniqueness of the above location, we studied about the diversity of actinomycetes in this location. This study was intended to be done as pioneer research in Eka Karya Botanical Garden. Several studies on diversity of actinomycetes were to be done in Indonesia, such as from Lombok Island (Lisdiyanti et al. 2012) and Cibinong Science Center (Widyastuti et al. 2013). To obtain new strains that can potentially produce new metabolites, it is still necessary to conduct exploration and examination of samples obtained from diverse habitats and environments. Few parts of the research had been orally presented in 2011 during Symposium on Recent Advances on Microbiological Researches and Its Application, conducted by Indonesian Society for Microbiology (PERMI) in Serpong.

\section{MATERIALS AND METHODS}

\section{Sampling Methods}

Soil samples were obtained from Eka Karya Botanical $\mathrm{G}$ arden located at 1,250-1,450 $\mathrm{m}$ above sea level, 115 $9^{\prime} 0-58^{\prime \prime} \mathrm{E}$ and $8^{\circ} 15-17^{\prime} 0-59^{\prime \prime} \mathrm{N}$, with 5-10 cm soil depth from soil surface. $\mathrm{pH}$ of the soil samples was between 6.0-6.5. The samples were immediately put into plastic bag. Decaying leaf-litter samples were collected from soil surface. The samples were immediately put into paper bag. All samples were air dried at room temperature for 1-2 weeks, ground using blender and filtered with $200 \mu \mathrm{m}$ mesh filter paper.

\section{SDS-Yeast E xtract (SY) Isolation Method}

SY isolation method was described by Widyastuti \&al. (2013). A combination of $0.05 \%$ SD S(Sodium D odecyl Sulphate) as a germicide to eliminate soil bacteria, $6 \%$ yeast extract as spore activating agents and heating at $40{ }^{\circ} \mathrm{C}$ for 20 minutes could also increases the recovery of actinomycetes from various soil samples. This method was used for isolating general actinomycetes.

\section{Rehydration and Centrifugation (RC) Isolation Method}

The RC isolation method was used for isolating motile actinomycetes. The sample is rehydrated by air-dried container in $10 \mathrm{mM}$ phosphate buffer containing 10\% soil extract, at 
$30^{\circ} \mathrm{C}$ for 90 minutes, followed by centrifugation at 1,500 x g for 20 minutes (Hayakawa \& al. 2000; O toguro đal. 2001; Widyastuti \&al. 2013).

\section{H umic Acid with Vitamins (HV) Medium}

$\mathrm{HV}$ medium was contained (in liter) $1 \mathrm{~g}$ humic acid, $0.02 \mathrm{~g} \mathrm{CaCO}_{3}, 0.01 \mathrm{~g} \mathrm{FeSO}_{4} .7 \mathrm{H}_{2} \mathrm{O}, 1.71 \mathrm{~g}$ $\mathrm{KCl}, 0.05 \mathrm{~g} \mathrm{MgSO}_{4} .7 \mathrm{H}_{2} \mathrm{O}, 0.5 \mathrm{gNaHPO}_{4}, 5 \mathrm{~mL}$ of vitamins solution, $50 \mathrm{mg}$ cycloheximide, $18 \mathrm{~g}$ agar, $\mathrm{pH}$ 7.2. The composition of vitamins solution was $0.5 \mathrm{mg}$ thiamine $\mathrm{HCl}, 0.5 \mathrm{mg}$ riboflavin, 0.5 mg niacin, $0.5 \mathrm{mg}$ pyridoxine $\mathrm{HCl}, 0.5 \mathrm{mg}$ inositol, $0.5 \mathrm{mg}$ Ca-panthotenate, $0.5 \mathrm{mg}$ p-aminobenzoic acid and $0.25 \mathrm{mg}$ biotin in $5 \mathrm{~mL}$ water and sterilized by $0.22 \mathrm{~m}$ filtration (Hayakawa \& Nonomura 1987). This vitamin solution was added after autoclave sterilization.

\section{Analysis of Diaminopimelic Acid (DAP)}

Preliminary biochemical test performed is the DAP determination using a method of thin layer chromatography (TLC) on cellulose to separate isomers of DAP (Hasegawa $\&$ al. 1983). Three loops of the cells was put in screw cap plastic tube, added with three drops of $6 \mathrm{~N} \mathrm{HCl}$, autoclaved at temperature of $121^{\circ} \mathrm{C}, 1 \mathrm{~atm}$ for 15 minutes, and then applied to cellulose chromatography plate. TLC eluent solution used was mixture of methanol: water: $6 \mathrm{~N} \mathrm{HCl}$ : pyridine (80: 26: 4: 10 $\mathrm{v} / \mathrm{v}$ ), and eluted for 12 hours. After that, the spots were sprayed with ninhydrin solution $(0.3 \mathrm{~g}$ ninhydrin in $100 \mathrm{~mL}$ of butanol $+3 \mathrm{~mL}$ of acetic acid), and heated at $100^{\circ} \mathrm{C}$ for 3 minutes.

\section{Preparation of Template DNA and PCR Amplification of 16SrRNA Gene}

Chromosomal DNA was extracted as described by Saito \& Miura (1963) from 14-dayold cell cultures grown on YG agar medium by using D Neasy Plant Maxi Kit (Q iagen). 16S rRNA gene replication reaction was performed using primer pair, 9F (forward: 5'-GAG TTTGATCCTGGCTCAG-3' positions 9-27) and 1541R (reverse: 5'-AAG G AG GTGATCCAGCC-3' position 1541-1525) of Esheidia di numbering system (Brosius \& al. 1978). PCR amplification was performed used TaKaRa ex Taq with total volume of $50 \mathrm{~L}$, consisting of $0.4 \mathrm{mM}$ of each primer, $1 \mathrm{ng}$ of D NA template, $2.5 \mathrm{mM}$ of dNTP, 1 of TaKaRa PCR buffer, and $5 \mathrm{U}$ of Taq polymerase in final volume. PCR conditions was $95^{\circ} \mathrm{C}$ for 3 minutes to denaturate the target $\mathrm{DNA}$, then by 30 cycles at $95{ }^{\circ} \mathrm{C}$ for 3 seconds for denaturation again, $55{ }^{\circ} \mathrm{C}$ for 15 minutes for primer annealing, and $72{ }^{\circ} \mathrm{C}$ for 1 minute for primer extension, and subsequently, 1 cycle at 72 ${ }^{\circ} \mathrm{C}$ for 5 minutes to complete the process of amplification. PCR reaction was conducted using a GeneAmp PCR System 9700 (Applied Biosystem). PCR products were examined by electrophoresis on agarose $2 \%$, to assure that the target DNA had been amplified. PCR products were then purified using the GFX-96 PCR Purification Kit (Amersham Pharmacia Biotech), with reference to the protocol.

\section{SrRN A Gene Sequencing}

PCR products that had been purified were cycle sequenced using the BigDye Terminator sequence with Version 3.1 Cycle Sequencing Kit. This reaction used 6 primers to amplify 1,500 bp of 16S rRNA gene, which is 9F, 515F (5'GTGCCAAGCAGCCG CGG T-3' position 515531), 1099F (5'-GCAACGAGCGCAACCC-3' position 1099-1114), 536R (5'-G TATTACCGCGGCTGCTTG -3' positions 536-519), 1115R (5'AGGGTTGCGTCGTTG-3' position 11151100), and 1541R of Escheidia cdi numbering system (Brosius \& al. 1978). In total $10 \mathrm{~L}$ of reaction sequence containing $2.0 \mathrm{~L}$ of Big Dye Terminator premix, $1.0 \mathrm{~L}$ of $5 \mathrm{Big}$ Dye sequencing buffer, $0.8 \mathrm{~L}$ of each primer $(1 \mathrm{pmol} / \mathrm{L})$, and $0.5 \mathrm{~L}$ of template DNA were synthesized of the chain by using a GeneAmp PCR System 9700 (Applied Biosystem) with the following conditions predenaturation at $96{ }^{\circ} \mathrm{C}$ for 1 minute, 45 cycles at a temperature of $96{ }^{\circ} \mathrm{C}$ for 10 seconds for denaturation, $50{ }^{\circ} \mathrm{C}$ for 5 seconds for primer annealing, and $60{ }^{\circ} \mathrm{C}$ for 90 seconds for primer extension, and subsequent to storage at $16^{\circ} \mathrm{C}$. The product was purified using D yeex $96 \mathrm{Kit}$ (Q iagen) and sequenced using ABI Prism 3700 (Applied Biosystem) DNA sequencer.

\section{Sequence Data Analysis and Alignment Search}

16S rD NA sequence was translated from the 16S rRNA gene by using ATGC Sequencing Analysis Software version 7.3 (ABI Prism) and corrected manually. Nucleotide sequence data of the isolates was searched the closest homology 
with other strains in the 16S rRNA gene data base using BLAST (http:/ / www.ncbi.nlm.nih. gov).

\section{RESULTS AND DISCUSSION}

From the total number of 38 samples consisted of 18 soil samples and 20 leaf-litter samples, 409 actinomycetes were isolated. A total of 229 isolates based on the colony appearance, were selected and used in this study. From 229 isolates, 144 were isolated from soil samples and 85 were isolated from leaf-litter samples. From soil samples, 60 and 84 actinomycetes were isolated by SY and RC isolation method, respectively; and 85 from leaf-litter samples were isolated by using RC isolation method (Table 1). The DAP analysis showed that within the actinomycetes isolated from soil source by SY isolation method, 18 isolates had LL-DAP, 31 isolates had meso LLmeso OH DAP, but the rest 11 isolates did not have DAP containing polymers. Actinomycetes isolated by RC isolation method showed that 24 isolates had LL-DAP, 48 isolates had meso DAP/ LL-meso OH in their cell wall, and the rest 12 isolates did not have DAP containing polymers. From leaf-litter source using RC isolation method, 3 isolates had LL-DAP, 66 isolates had moDAP/ LL-med O H on their cell wall, and 16 isolates did not have DAP containing polymers.

Table1 Number of isolated and selected actinomycetes from EkaK arya Botanical G arden, Indonesia

\begin{tabular}{|c|c|c|c|c|c|c|c|}
\hline \multirow{2}{*}{ Sampling site } & \multirow{2}{*}{ Source } & \multirow{2}{*}{$\begin{array}{l}\text { No. of } \\
\text { samples }\end{array}$} & \multirow{2}{*}{$\begin{array}{l}\text { Isolation } \\
\text { method }\end{array}$} & \multirow{2}{*}{ Selected isolates } & \multicolumn{3}{|c|}{ DAP isomer } \\
\hline & & & & & LL & M/ LL-M/ OH & ND \\
\hline \multirow{4}{*}{$\begin{array}{l}\text { Eka Karya } \\
\text { Botanical Garden }\end{array}$} & Soil & 18 & SY & 60 & 18 & 31 & 11 \\
\hline & & & $\mathrm{RC}$ & 84 & 24 & 48 & 12 \\
\hline & $\begin{array}{l}\text { Leaf- } \\
\text { litter }\end{array}$ & 20 & $\mathrm{RC}$ & 85 & 3 & 66 & 16 \\
\hline & & 38 & & 229 & 45 & 145 & 39 \\
\hline
\end{tabular}

Table 2 Actinomycetes isolated from Eka Karya Botanical Garden, Bali, Indonesia, 2003

\begin{tabular}{|c|c|c|c|c|c|c|c|c|c|c|}
\hline \multirow[b]{2}{*}{ No } & \multirow[b]{2}{*}{ Suborder } & \multirow[b]{2}{*}{ No } & \multirow[b]{2}{*}{ Family } & \multirow[b]{2}{*}{ No } & \multirow[b]{2}{*}{ Genus } & \multicolumn{4}{|c|}{ BLAST result } & \multirow[b]{2}{*}{ Total } \\
\hline & & & & & & $\begin{array}{c}>99 \\
\%\end{array}$ & $\begin{array}{l}98 \\
\%\end{array}$ & $\begin{array}{l}97 \\
\%\end{array}$ & $\begin{array}{l}<96 \\
\%\end{array}$ & \\
\hline \multirow{2}{*}{1} & \multirow{2}{*}{ Corynebacterineae } & \multirow{2}{*}{1} & \multirow{2}{*}{ Nocardiaceae } & 1 & Noardia & 2 & 5 & & 2 & 9 \\
\hline & & & & 2 & Rhodboocaus & & & & 1 & 1 \\
\hline \multirow{2}{*}{2} & \multirow{2}{*}{ Frankineae } & 2 & Cryptosporangiaceae & 3 & Cryptosparangum & & 1 & & & 1 \\
\hline & & 3 & Kineosporiaceae & 4 & Kineesparia* & & 7 & & 3 & 10 \\
\hline \multirow{2}{*}{3} & \multirow{2}{*}{ Micrococcineae } & 4 & Intrasporangiaceae & 5 & Lapilicocaus & & & & 1 & 1 \\
\hline & & 5 & Promicromonosporaceae & 6 & Promicamonospara & 1 & & & & 1 \\
\hline \multirow{7}{*}{4} & \multirow{7}{*}{ Micromonosporineae } & \multirow{7}{*}{6} & \multirow{7}{*}{ Micromonosporaceae } & 7 & Adinqplanes* & 8 & 33 & 22 & 4 & 67 \\
\hline & & & & 8 & Catellatospara & & 1 & & & 1 \\
\hline & & & & 9 & Catenulqplanes* & & 12 & 4 & & 16 \\
\hline & & & & 10 & Dactyosparangim* & & 3 & & & 3 \\
\hline & & & & 11 & Krasilnikoia* & & & 3 & & 3 \\
\hline & & & & 12 & Micramonospara & 3 & & 4 & 1 & 8 \\
\hline & & & & 13 & Vemucosispara & & & 1 & & 1 \\
\hline \multirow{2}{*}{5} & \multirow{2}{*}{ Propionibacterineae } & \multirow{2}{*}{7} & \multirow{2}{*}{ Nocardioidaceae } & 14 & Kribdla & 2 & & & & 2 \\
\hline & & & & 15 & Nocardidides & 1 & & & 1 & 2 \\
\hline \multirow{5}{*}{6} & \multirow{5}{*}{ Pseudonocarnineae } & \multirow{2}{*}{8} & \multirow{2}{*}{ Actinosynnemataceae } & 16 & Adindkineospora* & & 1 & & & 1 \\
\hline & & & & 17 & Sacharothrix & & 1 & & & 1 \\
\hline & & & & 18 & Amycolatopsis & 1 & 2 & & & 3 \\
\hline & & 9 & Pseudonocardiaceae & 19 & Psadonocardia & & 3 & 1 & & 4 \\
\hline & & & & 20 & Sacharomonospora & 1 & & & & 1 \\
\hline & & & & 21 & Kitasatospora & 5 & 2 & & & 7 \\
\hline 7 & Streptomycineae & 10 & Streptomycetaceae & 22 & Streptomyes & 42 & 24 & 4 & 3 & 73 \\
\hline & & 11 & Nocardiopsaceae & 23 & Noardiqpis & 4 & & & & 4 \\
\hline & & & & 24 & Acrocarpospora & & & & 1 & 1 \\
\hline 8 & Strentosnorancineae & 12 & Streptosporangiaceae & 25 & Nonomraø & 1 & 2 & 2 & & 5 \\
\hline 8 & Strepto sporangineae & & & 26 & Streptosparangum & 1 & & & & 1 \\
\hline & & & & 27 & Adtinocraliia & 1 & & & & 1 \\
\hline & & 13 & Thermomonosporaceae & 28 & Adtinomadura & & 1 & & & 1 \\
\hline & & & & & & 73 & 98 & 41 & 17 & 229 \\
\hline
\end{tabular}

Note: $*=$ Zoospore-bearing actinomycetes 
Table 3 Diversity of actinomycetes in soil samples

\begin{tabular}{|c|c|c|c|c|c|c|c|c|c|}
\hline No & Suborder & No & Family & No & Genus & $\begin{array}{l}\text { No of } \\
\text { species }\end{array}$ & $\mathrm{RC}$ & SY & Total \\
\hline \multirow{2}{*}{1} & \multirow{2}{*}{ Corynebacterineae } & \multirow{2}{*}{1} & \multirow{2}{*}{ Nocardiaceae } & 1 & Nocardia & 4 & 1 & 8 & 9 \\
\hline & & & & 2 & Rhodbocous & 1 & & 1 & 1 \\
\hline 2 & Frankineae & 2 & Kineosporiaceae & 3 & Kinesporia* & 1 & 1 & & 1 \\
\hline 3 & Micrococcineae & 3 & Promicromonosporaceae & 4 & Promicomonospora & 1 & 1 & & 1 \\
\hline \multirow{6}{*}{4} & \multirow{6}{*}{ Micromonosporineae } & \multirow{6}{*}{4} & \multirow{6}{*}{ Micromonosporaceae } & 5 & Adinqdanes* & 12 & 25 & & 25 \\
\hline & & & & 6 & Catellatospara & 1 & & 1 & 1 \\
\hline & & & & 7 & Dadylosparangin* & 1 & 3 & & 3 \\
\hline & & & & 8 & Krasilnikaia* & 1 & 3 & & 3 \\
\hline & & & & 9 & Mirarmmospora & 1 & & 2 & 2 \\
\hline & & & & 10 & Vemurosispora & 1 & 1 & & 1 \\
\hline 5 & Propionibacterineae & 5 & Nocardioidaceae & 11 & Kribbdla & 2 & & 2 & 2 \\
\hline & & & & 12 & Nocardidides & 2 & & 2 & 2 \\
\hline \multirow{4}{*}{6} & \multirow{4}{*}{ Pseudonocarnineae } & \multirow{2}{*}{6} & \multirow{2}{*}{ Actinosynnemataceae } & 13 & Adinkkineespora & 1 & 1 & & 1 \\
\hline & & & & 14 & Sachardthix & 1 & 1 & & 1 \\
\hline & & \multirow{2}{*}{7} & \multirow{2}{*}{ Pseudonocardiaceae } & 15 & Amyodatopsis & 2 & 1 & 2 & 3 \\
\hline & & & & 16 & Psandbocardia & 3 & 2 & 1 & 3 \\
\hline \multirow{2}{*}{7} & \multirow{2}{*}{ Streptomycineae } & \multirow{2}{*}{8} & \multirow{2}{*}{ Streptomycetaceae } & 17 & Kitasatospora & 5 & 6 & 1 & 7 \\
\hline & & & & 18 & Streptamyes & 36 & 33 & 32 & 65 \\
\hline \multirow{7}{*}{8} & \multirow{7}{*}{ Streptosporangineae } & 9 & Nocardiopsaceae & 19 & Nocardiqpsis & 4 & 2 & 2 & 4 \\
\hline & & \multirow{3}{*}{10} & \multirow{3}{*}{ Streptosporangiaceae } & 20 & Acroarpospora & 1 & 1 & & 1 \\
\hline & & & & 21 & Nonomraea & 3 & 2 & 3 & 5 \\
\hline & & & & 22 & Streptosparangum & 1 & & 1 & 1 \\
\hline & & \multirow{3}{*}{11} & \multirow{3}{*}{ Thermomonosporaceae } & 23 & Adinoccraliia & 1 & & 1 & 1 \\
\hline & & & & 24 & Adimmadura & 1 & & 1 & 1 \\
\hline & & & & & & 87 & 84 & 60 & 144 \\
\hline
\end{tabular}

Note: $*=$ zoospore bearing actinomycetes

Identification of 229 isolates based on 16S rRNA gene sequencing showed that the isolates belong to 8 suborders, 13 families and 28 genera of the class Actinomycetales (Table 2). The largest group of actinomycetes found belong to genus Streptomyces (73 isolates). The second largest group belong to genus Adinqplanes (67 isolates). The third largest group belong to genus Catenulqulanes (16 isolates). About 58 isolates $(25 \%)$ may be new species or new genus, because it has $<98 \%$ of $16 \mathrm{~S}$ rRNA gene similarity compared to the known strains in the database.

SY isolation method and cultures incubation on $\mathrm{HV}$ agar plates containing nalidixic acid introduced by Hayakawa and Nonomura (1989) improved the possibilities of isolating actinomycetes while decreasing the number of bacterial colonies. This method proved to be an effective tool for isolating actinomycetes. RC isolation method described by Hayakawa $\notin$ al. (2000) and O toguro \&al. (2001) was also found to be an effective tool for the isolation of zoospore from the genera of Adingdanes Adindkineospara, Adinosynnema, Catenuloplanes Dactylosparangim
Geodematophyus and Kineesporia. The phosphate buffer-soil extract solution significantly promoted liberation of motile zoospores from the source material, and the centrifugation eliminated Streptomyces and other non-motile actinomycetes. In general, actinomycetes isolated using SY method were dominated by many nonmotile actinomycetes, while those isolated using the RC method were dominated by motile actinomycetes. RC is an isolation method developed for isolating motile zoospore (Hayakawa etal. 2000).

All 229 selected isolates were identified using molecular identification procedure based on full sequence of $16 \mathrm{~S}$ rRNA gene $( \pm 1,500 \mathrm{bp})$. The isolates were further identified into genus and species level by BLAST and phylogenetic tree construction. Currently, actinomycetes consisted of 24 families, 80 genera and 500 species (Liu $\notin a l$. 2009). In our study, we could identify 8 suborders, 13 families and 28 genera (Table 3). We predicted that there were more than 109 species. This is the first comprehensive study of actinomycetes conducted in Eka Karya Botanical Garden, Bali Island, Indonesia. 


\section{Diversity of Actinomycetes on Soil Samples}

From soil samples, we obtained 144 isolates of actinomycetes that had been identified by $16 \mathrm{~S}$ rRNA gene analysis and preserved well in liophilized form. The isolates contained 24 genera and more than 87 species. The most dominated genera in the soil samples was Stretamyes (65 isolates $=45 \%)$ and the next was Adimqulanes $(25$ isolates $=17 \%$ ).

Based on the isolation methods, 15 genera (60 isolates) were successfully isolated by SY isolation method and 16 genera (84 isolates) were isolated by RC isolation method. Genera of Nocardia, Rhoobocoas, Catdatospora, Micrommospora, Kribbella, Nocardidids Streptosporangum Adinocoralia and Adinamadura were easily isolated using SY isolation method; while RC method was useful for isolating genera Adinoplanes Krasilnikovia, Dadylosporangum Vemucosispora, Adindkinespora and Sacharothix. Most of soil actinomycetes isolated by $\mathrm{RC}$ isolation method belong to zoospore bearing actinomycetes. By using different isolation method, the dominant species of actinomycetes isolated were also different. In this study, we proved that actinomycetes isolated using the RC method were dominated by groups of zoospore bearing actinomycetes. This result is similar to that described by Hayakawa \&al. (2000) and O toguro eal. (2001).

Several ecological factors that played a role in the distribution of generaactinomycetes included humus content and pH of the soil (Nonomura \& Hayakawa 1988), climate may influence the specific type of soil-inhabiting actinomycetes (Hayakawa \& al. 2010). Soil of Eka Karya Botanical Garden is a humus-rich soil with $\mathrm{pH}$ range from 6 to 6.5 . This soil type is suitable for thegrowth of actinomycetes.

Some of actinomycetes are distributed in plant rhizosphere soils. Diverse plant species found in the garden should also support the growth of actinomycetes. Actinomycetes have been found to play an important role in rhizosphere soil (Suzuki đal. 2000; El-Tarabily \& Sivasithamparam 2006). There is a possibility that these microorganisms can protect plant roots from plant pathogen and promote plant growth.

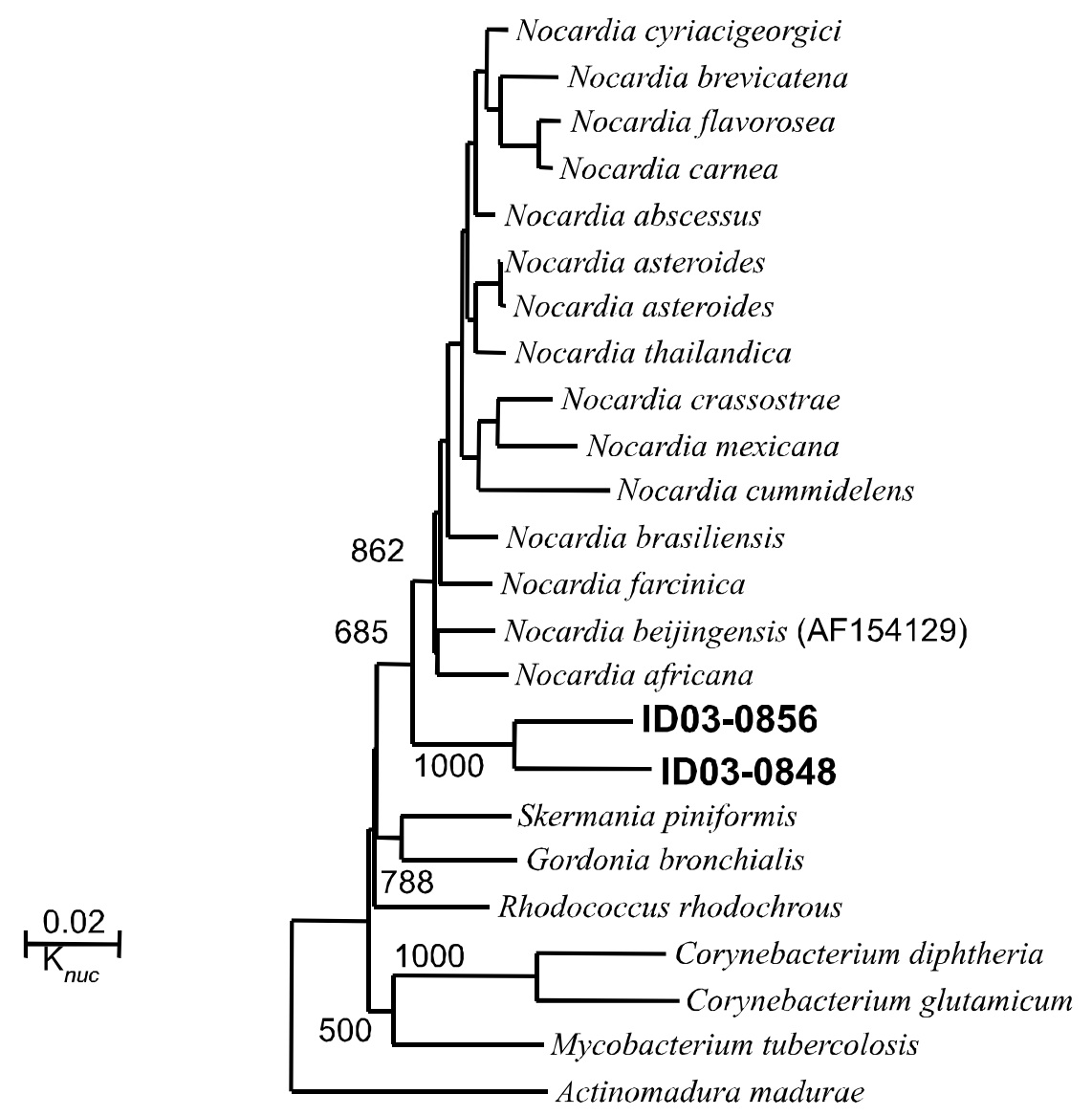

Figure 1 Phylogenetic position based on 16SrRNA sequences of several isolates under the Nocardiagenera from Eka Karya Botanical Garden. Bar, 1 substitutions per 200 nucleotides 
For plant root protection, the modes of action of actinomycetes include antibiosis, parasitism, the production of extracellular hydrolytic enzymes and competition for iron (Getha \& al. 2005; Errakhi $\notin$ al. 2007). SY isolation method was particularly successful for isolating common actinomycetes such as Streptomyes spp. In natural habitats, streptomycetes are common and are usually a major component of the total actinomycetes population. Kim (1984) reported that within population in the soil, actinomycetes are dominated by Streptomyes $(95.43 \%)$.

Identification by molecular approach indicated that actinomycetes obtained from Eka Karya Botanical Garden should have potential value as a source to find new species or new genus. Based on the analysis of $16 \mathrm{~S}$ rRNA gene, $<97 \%$ sequence were in homology with the closest species on BLAST searching compared to the current database. N ew species and new genus among the strains studied were obvious. The16S rRNA gene sequence of strain ID 03-0848 and ID 03-0856 were aligned with those of the type species of the major Nocardia and other actinomycete lineages. The resulting phylogenetic tree is shown in Figure 1. Strain ID 03-0848 and ID 03-0856 formed a coherent clade within the Nocardialineage, clearly distinguished from other described strains with highly bootstrap value. This was suspected to be new genus or new species in the Nocardalineage.

\section{Diversity of Actinomycetes on Leaf-litter Samples}

Meanwhile, from the leaf-litter as a source material, we obtained 85isolates of actinomycetes that had been identified by $16 \mathrm{~S}$ rRNA gene analysis and preserved well in liophilized form. The isolates contained 9 genera (Table 4) and more than 41 species. The most dominated genus was Adimgdanes (42 isolates $=49 \%$ ) and the next was Catenulqulanes (16 isolates $=19 \%$ ) and Kineosporia (9 isolates $=10 \%$ ). The same as in soil samples, most of the leaf-litter actinomycetes isolated by RC method belong to the zoospore bearing actinomycetes. This finding is in agreement with other reports which mentioned that actinomycetes belonging to genera Adimplanes Catenulqulanes and Kinesporia were frequently isolated from leaf-litter samples (Pagani \& Parenti 1978; Kudo \& al. 1998; Hayakawa $\notin$ al. 2000; Ratnakomala $\notin$ al. 2011). They showed very similar characteristics such as possession of motility, absence or rarity of hydrophobic aerial hyphae and formation of orange colonies, similar to the color of fallen leaves (Van Hop eal. 2011).

Xu \& al. (1996) and Meliani \& al. (2012) reported that there was a positive correlation between diversity of actinomycetes with vegetation. Land of primary forest has higher diversity of actinomycetes compared with land of secondary forest and agricultural land. O n dry, barren and cold land, there are less actinomycetes found (Xu \&al. 1996; G arrity \&al. 1996). Search of new active compounds, especially from actinomycetes requires a large number of isolates. It would be more promising if sampling and isolation techniques are more specific (Lo $\notin$ al. 2002). Therefore, it is essential to look for unique types of vegetation where the soil sample will be taken for finding new taxonomically important actinomycetes. It is also important to find

Table 4 Diversity of actinomycetes from leaf-litter samples

\begin{tabular}{|c|c|c|c|c|c|c|c|}
\hline No & Suborder & No & Family & No & Genus & $\begin{array}{c}\text { No of } \\
\text { species }\end{array}$ & $\mathrm{RC}$ \\
\hline \multirow{2}{*}{1} & \multirow{2}{*}{ Frankineae } & 1 & Cryptosporangiaceae & 1 & Cryptosprangium & 1 & 1 \\
\hline & & 2 & Kineosporiaceae & 2 & Kineosporia* & 1 & 9 \\
\hline \multirow[t]{2}{*}{2} & Micrococcineae & 3 & Intrasporangiaceae & 3 & Lapilicous & 1 & 1 \\
\hline & & & & 4 & Adingdanes* & 21 & 42 \\
\hline \multirow[t]{2}{*}{3} & Micromonosporineae & 4 & Micromonosporaceae & 5 & Catenulopdanes* & 2 & 16 \\
\hline & & & & 6 & Micrommospara & 6 & 6 \\
\hline \multirow{2}{*}{4} & Pseudonocarnineae & 5 & Pseudonocandiaceae & 7 & Psardanocardia & 1 & 1 \\
\hline & rseudonocarnmeae & & & 8 & Sacharommospara & 1 & 1 \\
\hline \multirow[t]{2}{*}{5} & Streptomycineae & 6 & Streptomycetaceae & 9 & Streptamyces & 7 & 8 \\
\hline & & & & & & 41 & 85 \\
\hline
\end{tabular}

Note: $^{*}=$ zoospore bearing actinomycetes 


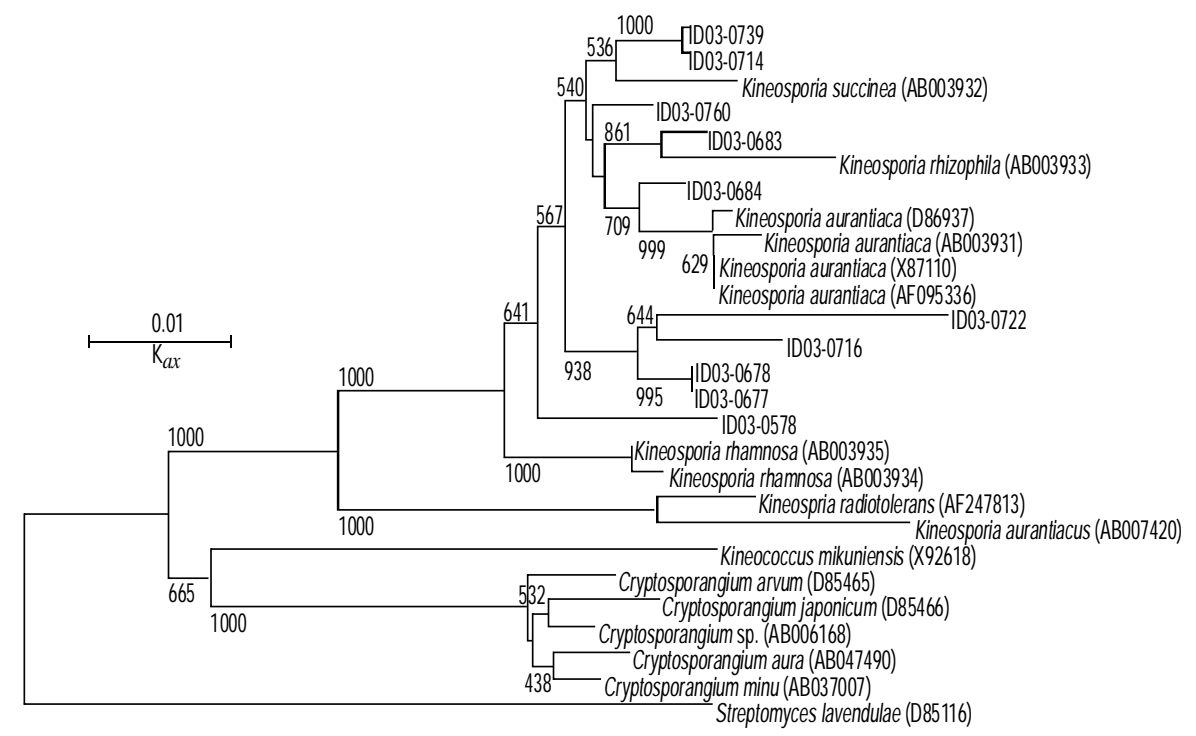

Figure 2 Phylogenetic position based on 16S rRNA sequences of several isolates under the Kineosporia genera from Eka K arya Botanical G arden. Bar, 1 substitution per 100 nucleotides

actinomycetes with new metabolic properties. There is a possibility to find a new actimomycete species for the production of new antibiotics or other secondary metabolites. These microbes will specifically generate new secondary metabolites which allow them to degrade toxic compounds from these plants (Park \&al. 1999; Ho e al. 2000). Eka Karya Botanical Garden is one place for ex situ plant conservation of tropical forests in Indonesia. It is understood that high diversity of actinomycetes will likely to be found in such place.

Selection of proper method of isolation is crucial to obtain new actinomycetes species. It was obvious from our study that the use of $\mathrm{RC}$ method was significantly useful to isolate new species from leaf-litter samples, especially from genus Kinesspona The 16S rRNA gene sequences of 10 strains (ID 03-0578, ID 03-0677, ID 03-0678, ID 03-0683, ID 03-0684, ID 03-0714, ID 03-0716, ID 03-0722, ID 03-0739 and ID 03-0760) were aligned with those of type species of the major Kineosporia and other actinomycete lineages. As shown in Figure 2, strain ID 03-0739 and ID 030714 were moderately related to the type strain $K$ surcina AB003932. Strain ID 03-0683 and ID 03-0760 were related to type strain $\mathrm{K}$ rizqpila AB003933. Strain ID 03-0684 was closely related to type strain K aurantiaca D 86937. Strain ID 030677 and ID 03-0678 shared the same branching position and formed a single clade with ID 030716 and ID 03-0722. These four strains were clearly distinguished from other described strains with highly bootstrap value. This was suspected to be new genus or new species in the Kinesporia lineage.

This study is significantly important to describe the diversity of actinomycetes in Indonesia. There are ample spaces to use isolated actinomycetes for the benefit of society. Further research on several important taxa including proposing new species or genus is mandatory. More data on phenotype, biochemical characterization, DNA-DNA hybridization and chemotaxonomic are required.

\section{CONCLUSIONS}

Selection of proper isolation method is crucial to obtain a new actinomycetes species. Using SY isolation method, this research was successfully isolated 2 new species of actinomycetes from $E$ ka Karya Botanical Garden. This study is significantly important to describethe diversity of actinomycetes in Indonesia. There are ample space to use isolated actinomycetes for the benefit of society. Further research on some important taxa including for proposing new species or genus is mandatory. More data on phenotypic, biochemical characterization, D NA hybridization and chemotaxonomic data are required to describe the other actinomycetes candidates as new species. 


\section{ACKNOWLEDGEMENTS}

This study was conducted under the Joint Research Project between Department of Biotechnology, National Institute of Technology and Evaluation, Japan and the Indonesian Institute of Sciences (LIPI) representing Indonesian G overnment Research Institutes. The authors thanked Eka Karya Botanical Garden, LIPI and technicians in NITE and Research Center for Biotechnology LIPI for their assistance.

\section{REFERENCES}

Baskaran R, Vijayakumar R, Mohan PM. 2011. Enrichment method for the isolation of bioactive actinomycetes from mangrove sediments of Andaman Islands, India. Malay J Microbiol 7(1):26-32.

Bredholt H, Fjærvik E, Johnsen G, Zotchev SB. 2008. Actinomycetes from sediments in the Trondheim Fjord, Norway: diversity and biological activity. Mar D rugs 6(1):12-24.

Brosius J, Palmer ML, Kennedy PJ, Noller HF. 1978. Complete nucleotide sequence of a $16 \mathrm{~S}$ ribosomal RNA gene from Escheidhia odi. Proc Natl Acad Sci 75(10):4801-5.

Cross T. 1986. The occurrence and role of actinoplanetes and motile actinomycetes in natural ecosystems. In: Megusar F, Gantar M, (Eds). Perspectives in microbial ecology. Proceedings of the IV International Symposium on Microbial Ecology. $p$ 265-70.

El-Tarabily KA, Sivasithamparam K. 2006. Nonstreptomycete actinomycetes as biocontrol agents of soil-bome fungal plant pathogens and as plant growth promoters. Soil Biol Biochem 38: 1505-20.

Errakhi R, Bouteau F, Lebrihi A, Barakate ML. 2007. Evidences of biological control capacities of Streptamyes spp. against Sderdiumrdfsii responsible for damping disease in sugar beet (Beta vilganis L.). World J Microbiol Biotechnol 23:1503-9.

Garrity G M, Heimbuch BK, Gagliardi M. 1996. Isolation of zoosporogenous actinomycetes from desert soils. J Ind Microbiol 17:260-7.

Getha K, Vikineswary S, Wong WH, Seki T, Ward A, Goodfellow M. 2005. Evaluation of Streptomyes sp. strain g10 for suppression of Fusanium wilt and rhizosphere colonization in pot-grown banana plantlets.J Indian Microbiol Biotechnol 32:24-32.

Hasegawa T, Takizawa M, Tanida S. 1983. A rapid analysis for chemical grouping of aerobic actinomycetes. J Gen Appl Microbiol 29:319-22.
Hasegawa T. 1991. Studies on Motile Arthrospore-Bearing RareActinomycetes. Actinomycetol 5(2):64-71.

Hayakawa M, Nonomura H. 1987. Efficacy of artificial humic acid as a selective nutrient in HV agar used for the isolation of soil actinomycetes. J Ferment Technol 65(6):609-16.

Hayakawa M, Nonomura H. 1989. A new method for the intensive isolation of Actinomycetes from soil. Actinomycetol3(2):95-104.

Hayakawa M, O toguro M, Takeuchi T, Yamazaki T, Iimura Y. 2000. Application of a method incorporating differential centrifugation for selective isolation of motile Actinomycetes in soil and plant litter. Antonie van Leeuwenhoek 78:171-85.

Hayakawa M. 2008. Studies on the isolation and distribution of rare Actinomycetes in soil. Actinomycetolo 22:12-9.

Hayakawa M, Yamamura H, Sakuraki Y, Ishida Y, Hamada M, O toguro M, Tamura T. 2010. D iversity analysis of Actinomycetes assemblages isolated from soils in cool-temperate and subtropical areas of Japan. Actino mycetol 24:1-11.

Ho CC, Tan GYA, Seow I, Ajam N, Tan EI, Goodfellow M, Ward AC, Brown R, Wong NK, Lo CW, Cheah HY, Lai NS, Suzuki KI. 2000. Isolation, characterization and biological activities of actinomycetes isolated from dipterocarp rain forest soils in Malaysia. In: Nnga BH, Tan HM, Suzuki K-I, editor. Miadidoy Divesity in Asia Singapore: World Scientific.

Hopwood DA. 2007. Streptomycesin NatureandMediane, The AntibidicMakess UK: O xford University Press, Inc.

K hamna S, Yokota A, Peberdy JF, Lumyong S. 2010. Indole3-acetic acid production by Streptomycessp. isolated from some Thai medicinal plant rhizosphere soils. EurAsiaJ BioSci 4:23-32.

Khanna M, Solanki R, Lal R. 2011. Selective isolation of rare Actinomycetes producing novel antimicrobial compounds. IntJ Adv Biotechnol Res2(3):357-75.

Kim CJ. 1984. Isolation and screening of Actinomycetes from natural environments. Sweden: G enetic Engineering Research Institute, KIST.

Kudo T, Matsushima K, Itoh T, Sasaki J, Suzuki K. 1998. Description of four new species of the genus Kimeesporia Kineesporia sucinea sp. nov., Kineesporia hizqphila sp. nov., Kineesporia mikuniensis sp. nov. and Kinesponia rhamosa sp. nov., isolated from plant samples, and amended description of the genus Kineosporia IntJ Syst Bacteriol 48:1245-55.

Liu N, Wang H, Liu M, Gu Q, Zheng W, Huang Y. 2009. Strettomyes alni sp. nov., a daidzein-producing endophyte isolated from a root of Alnus nepalensis D.D on. Int J Syst Evol Microbiol 59:254-58.

Lo CW, Lai NS, Cheah HY, Wong NKI, Ho CC. [Internet]. 2002. Actinomycetes isolated from soil samples 
from the crocker range Sabah. Malaysia: ASEAN Review of Biodiversity and Environmental Conservation. Available from: http:/ / www.arbec. com.my/ pdf/ art21julysep02.pdf.

Lisdiyanti P, Tamura T, Ratnakomala S, Ridwan R, Kartina G, Lestari Y, Katsuhiko A, Widyastuti Y. 2012. Diversity of Actinomycetes from Soil Samples Collected from Lombok Island, Indonesia. Annales Bogorienses 16(1):35-40.

Meliani A, Bensoltane A, Mederbel K. 2012. Microbial diversity and abundance in soil: related to plant and soil type. Am J Plant NutFert Technol Academic Journals Inc 2(1):10-8.

Miyadoh S. 2004. AntibidicScreeningfiromA dinmyctelsolates Bogor: Workshop on Isolation Methods and Classification of Actinomycetes.

Mukaromah L, Suparta IP. 2007. Flowering biology of Paphiqpeedilumjavaniam(Reinw. Ex Lindl) Pfitzer. In: Eka Karya Botanical Garden. Bogor (ID): Kebun Raya Bogor. p 80-4.

Nonomura H, Hayakawa M. 1988. NewMethodsfortheSdetive Isdationof Soil Adinomyctes InBidogyof Adinomyctes In: O kami Y, Beppu T, Ogawara H, editor. Tokyo (JP): Japan Scientific Societies.

O toguro M, Hayakawa M, Yamazaki T, Iimura Y. 2001. An integrated method for the enrichment and selective isolation of Adindkinespora spp. in soil and plant litter.J A ppl Microbiol 91:118-30.

Pagani H, Parenti F. 1978. Kineosporia, a new genus of the order Actinomycetales. Int J Syst Bacteriol 28:401-6.

Park DJ, Lee SH, Kim CI, Uramoto U. 1999. Isolation of rare Actinomycetes from soil samples in specific micro-environments-natural lime cave and plant rhizosphere soil. Proceedings of International Conference on Asian Network on N Microbial Research. Thailand. p 728-37.
Ratnakomala S, Ridwan R, Lisdiyanti P, Abinawanto, Utama A. 2011. Screening of Actinomycetes producing an ATPase inhibitor of RNA helicase from soil and leaf litter samples. Microbiol Indones 5(1):15-20.

Saito H, Miura K. 1963. Preparation of transforming deoxyribonucleic acid by phenol treatment. Biochimica et Biophysica Acta 72:619-29.

Sibanda T, Mabinya LV, Mazomba D, Akinpelu DA, Bernard K, Olaniran AO, O koh AI. 2010. Antibiotic producing potentials of three freshwater Actinomycetes isolated from the Eastern Cape Province of South Africa. IntJ Mol Sci 11:2612-23.

Stackebrandt E, Rainey FA, Ward-Rainey NL. 1997. Proposal for a new hierarchic classification system, Adimdbacteia dassis nov. Int J Syst Bacteriol 47: 479-91.

Suzuki S, Yamamoto K, Okuda T, Nishio M, Nakanishi N, Komatsubara S. 2000. Selective isolation and distribution of Adinomadura nugatdispora strains in soil. Actinomycetol14:27-33.

Tamura T, Ishida Y, Otoguro M, Suzuki K. 2010. Amyodatopsis heveeda sp. nov. and Amydatopis pignetatasp. nov. isolated from soil. Intl J Syst Evol Microbiol60:2629-33.

VanHop D, Sakiyama Y, Binh CTT, O toguro M, Hang D T, Miyadoh S, Luong DT, Ando K. 2011. Taxonomic and ecological studies of Actinomycetes from Vietnam: isolation and genus-level diversity. J Antibiot64:599-606.

Widyastuti Y, Lisdiyanti P, Ratnakomala S, Kartina G, Ridwan R, Rohmatussolihat R, Ando K. 2013. Genus diversity of Actinomycetes in Cibinong Science Center, West Java, Indonesia. Microbiology Indonesia 6(4):165.

Xu LH, Li QR, Jiang CL. 1996. Diversity of soil Actinomycetes in Yunnan, China. Appl Environ Microbiol62(1):244-8. 